Volume 3 Issue 1, March 2019: pp. 132-156. Copyright (c) 2019 HOLREV. Faculty of Law, Halu Oleo University, Kendari, Southeast Sulawesi, Indonesia. ISSN: 2548-1762 | e-ISSN: 2548-1754. Open Access at: http://ojs.uho.ac.id/index.php/holrev/

\title{
Relasi Kuasa-Pengetahuan dalam Sistem Ketatanegaraan di Kerajaan Konawe Abad Ke-XVII: Telaah Epistemologi Siwole Mbatohu
}

\author{
Power-Knowledge Relation in the Constitutional Law System of Konawe \\ Kingdom at XVII Century: Epistemological Inquiry of Siwole Mbatohu
}

\author{
Idaman \\ Fakultas Hukum, Universitas Halu Oleo \\ E-mail:idam_idea@uho.ac.id
}

\begin{abstract}
Siwole Mbatohu is a political conceptual in the Konawe kingdom, primarily in the era of Mokole Tebawo (Sangia Inato). The division of several regions into four autonomous regions by means of political and economic resilience over the region of Konawe kingdom. The region of Siwole Mbatohu are: western region as usually called Tambo i Tepuli, ano Oleo (the sunset gate) with positioned in Latoma lead by Sabandara, eastern region of Konawe kingdom as usually called tambo i Losoano Oleo (the rising sun gate) with positioned in Ranomeeto lead by Sapati, the right side of Konawe kingdom as usually called Bharata i Hanano Wuta Konawe with positioned in Tongauna lead by Ponggawa, and the left side of Konawe kingdom as usually called Bharata i Moerino Wuta Konawe with positioned in Asaki lead by Inowa.

Several manuscripts of Siwole Mbatohu merely struggling of analyzing toward a security defense. The writers assert that the division of territory by Mokole was mean of security defense of Konawe kingdom. even though, if it is examined, primarily by using of foucault's power relation (power/knowledge), it is clearly visible that the division of region was done in the frame of maintaining of power. It is clearly strengthened by historical reasons, that This is reinforced by historical reasons, that before the division of the territory was carried out, there was a complicated problem which almost led to civil war in the center of the kingdom of Konawe, Inolobunggadue.

In epistemological inquiry, especially political epistemology, the concept of Siwole Mbatohu was produced in order to perpetuate the status quo, strengthen power, and control of power in the four small kingdoms, namely wings and gates. These relations were built to legitimize the power of the Konawe kingdom center as a genealogical entity that had links with other regions in Siwole Mbatohu. The mention of mokole Tebawo, and even the kings of pre-Islamic Konawe as sangia (gods) indicate that
\end{abstract}


mokole is the embodiment of gods, a symbol of strength, the most authoritative place of rest for all communities in the Konawe kingdom.

Keyword: Siwole Mbatohu; power/knowledge relation; epistemology; status quo

\begin{abstract}
Abstrak: Siwole Mbatohu adalah konseptual politik di kerajaan Konawe, terutama di era Mokole Tebawo (Sangia Inato). Pembagian beberapa daerah otonom dengan cara ketahanan politik dan ekonomi atas wilayah kerajaan Konawe. Wilayah Siwole Mbatohu adalah: Wilayah bagian barat kerajaan Konawe yang disebut Tambo i Tepuli, ano Oleo yang berkedudukan di Latoma dipimpin oleh Sabandara, wilayah bagian Timur kerajaan Konawe yang disebut tambo i Losoano Oleo berkedudukan di Ranomeeto yang dipimpin oleh Sapati, wilayah bagian Kanan (Utara) kerajaan Konawe yang disebut Bharata i Hanano Wuta Konawe yang berkedudukan di Tongauna dipimpin oleh Ponggawa, dan wilayah bagian kiri (Selatan) kerajaan Konawe yang disebut Bharata i Moerino Wuta Konawe berkedudukan di Asaki yang dipimpin Inowa.

Beberapa manuskrip Siwole Mbatohu hanya berjuang untuk menganalisis pertahanan keamanan. Para penulis menyatakan bahwa pembagian wilayah oleh Mokole adalah pertahanan keamanan kerajaan Konawe, walaupun jika dikaji, terutama dari penggunaan hubungan kekuasaan (power/knowledge), terlihat jelas bahwa pembagian wilayah dilakukan dalam rangka mempertahankan kekuasaan. Itu adalah alasan historis, yaitu alasan historis, yaitu sebelum pembagian kerajaan Konawe, Inolobunggadue.

Dalam penyelidikan epistemologi, terutama epistemologi politik, konsep Siwole Mbatohu telah diproduksi untuk mengabadikan status quo, memperkuat kekuasaan, dan mengendalikan kekuasaan di empat kerajaan kecil, yaitu sayap dan gerbang. Hubungan ini dibangun untuk melegitimasi kekuatan pusat kerajaan Konawe sebagai entitas silsilah yang terhubung dengan wilayah lain di Siwole Mbatohu. Penyebutan Mokole Tebawo, dan bahkan raja-raja Konawe pra-Islam sebagai sangia (dewa) menunjukkan bahwa mol adalah perwujudan dewa, simbol kekuatan, tempat peristirahatan yang paling otoritatif untuk semua komunitas di kerajaan Konawe.
\end{abstract}

Kata kunci: Siwole Mbatohu; hubungan kekuasaan/pengetahuan; epistemologi; status quo

\title{
PENDAHULUAN
}

Sistem nilai yang telah lama hidup dalam masyarakat lokal selanjutnya menjadi pedoman dalam perilaku masyarakat sehari-hari. Sistem nilai ini sering kali menempati hierarki tertinggi dibandingkan dengan nilai-nilai lain. Hal ini disebabkan oleh konsepsi masyarakat tentang nilai tersebut merupakan sesuatu yang sangat penting dan menjadi pengetahuan lokal (local wisdom) yang terus menerus dipertahankan. Sistem nilai tersebut misalnya adat istiadat dan sistem politik tradisional. Sistem terakhir ini hingga saat ini masih terus dipertahankan di dalam rangka mengatur tata hubungan masyarakat lokal. Implikasinya, menguatnya kembali hubungan patron klien antara masyarakat kelas atas, 
menengah dan bawah. Hubungan patron klien ini secara embrional berasal dari bangunan sistem birokrasi tradisional pada masa kerajaan pra-kolonial. Kondisi ini menjadi perhatian serius Ahimsa-Putra ${ }^{1}$ ketika melakukan penelitian mengenai hubungan patron klien di Sulawesi Selatan. Nilai-nilai tradisional dalam hubungannya dengan birokrasi prakolonial ini saat ini diyakini masih layak dipertahankan dan dikontekstualisasikan.

Rekonstruksi nilai-nilai kehidupan masa lalu, khususnya yang berkenan dengan hukum dan sistem bernegara tampaknya menjadi penting saat ini. Asumsi ini didasarkan kepada pandangan bahwa karakteristik dan identitas suatu bangsa sangat menentukan dasar-dasar kebangsaan dan kenegaraan di dalam konstitusi. Hal itu dapat dilihat dari salah satu konsensus dasar yang termaktub dalam konstitusi, yaitu kesepakatan tentang tujuan atau cita-cita bersama (the general goals of society or general acceptance of the same philosophy of government). ${ }^{2}$ Pandangan ini, bagi Asshiddiqie, ${ }^{3}$ memiliki konsekuensi bahwa konstitusi selalu dibuat dan berlaku untuk suatu negara tertentu. Konstitusi dibuat berdasarkan pengalaman dan akar sejarah suatu bangsa, kondisi yang sedang dialami, serta cita-cita yang hendak dicapai.

Setiap bangsa dan peradaban memiliki karakter yang unik. Bahkan setiap bangsa memiliki karakter dan kualitas tersendiri yang secara intrinsik tidak ada yang bersifat superior satu di antara yang lainnya. Dalam hubungannya dengan pembentukan sistem hukum, von Savigny menyatakan bahwa suatu sistem hukum adalah bagian dari budaya masyarakat. Hukum tidak lahir dari suatu tindakan bebas (arbitrary act of a legislator), tetapi dibangun dan dapat ditemukan di dalam jiwa masyarakat. Hukum secara hipotetis dapat dikatakan berasal dari kebiasaan dan selanjutnya dibuat melalui suatu aktivitas hukum (juristic activity). ${ }^{4}$

1 Shri Heddy Ahimsa-Putra, Minawang: Hubungan Patron Klien di Sulawesi Selatan. Yogyakarta: Gadjah Mada University Press, 1988.

2 William G. Andrews, Constitutions and Constitutionalism 3rd edition. New Jersey: Van Nostrand Company, 1968, hlm. 12-13.

3 Jimly Asshiddiqie, Konstitusi dan Hukum Tata Negara Adat. Disampaikan sebagai bahan Keynote Speech pada Seminar Nasional tentang Konstitusi Kesultanan-Kesultanan Islam di Jawa Barat dan Banten. UIN Gunung Djati, Bandung, 5 April 2008.

4 M.D.A. Freeman, Lloyd's Introduction to Juricprudence, Seventh Edition, London: Sweet \& Maxweel Ltd, 2001, hlm. 904-905. Lihat juga, Absori, Kelik Wardiono dan Saepul Rochman, Hukum Profetik: Kritik Terhadap Paradigma Hukum Non-Sistematik. Yogyakarta: Genta Publishing, 2015, hlm.104. Hayatul Ismi, "Pengakuan dan Perlindungan Hukum Hak Masyarakat Adat atas Tanah Ulayat dalam Upaya Pembaharuan Hukum Nasional”, Jurnal Ilmu Hukum, Vol. 2, 2 Februari 2012, hlm. 135-137. Istilah "bagian dari budaya masyarakat", bagi von Savigny disebut sebagai Volksgeist. Istilah ini, Volksgeist "means the general or common consciousness or the popular spirit of the people. Savigny believed that law is the product of the general consciousness of the people and a manifestation of their spirit. The basis of origin of law is to be found in Volksgeist which means people"s consciousness or will and consists of traditions, habits, practice 
Pandangan tersebut di atas bermuara kepada kenyataan, bahwa akar hukum dan ketatanegaraan suatu bangsa yang diatur dalam konstitusi dapat dilacak dari sejarah bangsa itu sendiri. Dalam konteks Indonesia, akar ketatanegaraan Indonesia modern dapat dilacak dari Hukum Tata Negara Adat yang pernah berlaku di kerajaan-kerajaan atau kesultanan-kesultanan yang pernah hidup di wilayah nusantara. Bahkan hukum tata negara adat juga masih dapat dijumpai hidup dan berlaku dalam lingkup masyarakat hukum adat. ${ }^{5}$

Pengakuan terhadap nilai-nilai tradisional di dalam masyarakat Indonesia tampaknya terlihat dalam proses pembahasan UUD 1945 oleh BPUPK menunjukkan bahwa UUD 1945 dibuat dengan cita-cita dan spirit yang berakar dari semangat bangsa Indonesia yang khas, serta pengalaman ketatanegaraan adat yang telah dipraktikkan oleh masyarakat Indonesia. Hal itu dapat dilihat dari pidato Soekarno, Soepomo, bahkan Muhammad Yamin. Spirit bangsa Indonesia dari semua golongan yang ada diungkapkan oleh Soekarno menjadi lima dasar, yaitu Pancasila. Inilah salah satu bentuk kesepakatan mengenai filosofi pemerintahan yang dapat disepakati bersama (general acceptance of the same philosophy of government) . Kesepakatan tersebut terjadi karena Pancasila memiliki akar dalam masyarakat Indonesia sehingga disetujui oleh para pendiri bangsa, sebagaimana dikemukakan dalam pidato Soekarno berikut ini.

Kita bersama-sama mentjari philosophische grondslag, mentjari satu "Weltanschauung" jang kita semuanja setudju. Saja katakan lagi setudju! Jang saudara Yamin setudjui, jang Ki Bagoes setudjui, jang Ki Hadjar setudjui, jang saudara Sanoesi setudjui, jang saudara Abikoesno setudjui, jang saudara Lim Koen Jian setudjui, pendeknja kita semua mentjari satu modus. ${ }^{6}$

Akar hukum dan ketatanegaraan suatu bangsa yang diatur dalam konstitusi dapat dilacak dari sejarah bangsa itu sendiri. Dalam konteks Indonesia, akar ketatanegaraan Indonesia modern dapat dilacak dari hukum tata negara adat yang pernah berlaku di kerajaan-kerajaan atau kesultanan-kesultanan yang pernah hidup di wilayah nusantara.

and beliefs of the people. The concept of Volksgeist in German legal science states that law can only be understood as a manifestation of the spirit and consciousness of the German people'. Lihat, Mathias Reimann, The Historical School Against Codification: Savigny, Carter, and the Defeat of the New York Civil Code, 37 AM. J. COMP. L. 95, 97-98 (1989), Doherty Michele, Jurisprudence: The Philosophy of Law, 2nd ed., London: Old Bailey Press, 2001, hlm. 233.

5 Jimly Asshiddiqie, Konstitusi dan Hukum Tata Negara Adat. Disampaikan sebagai bahan Keynote Speech pada Seminar Nasional tentang Konstitusi Kesultanan-Kesultanan Islam di Jawa Barat dan Banten. UIN Gunung Djati, Bandung, 5 April 2008.

6 Muhammad Yamin, Naskah Persiapan Undang-Undang Dasar 1945, Djilid Pertama, Jakarta: Siguntang, 1959, hlm. 68 
Bahkan hukum tata negara adat juga masih dapat dijumpai hidup dan berlaku dalam lingkup masyarakat hukum adat. Oleh karena itu, mempelajari hukum tata negara adat diperlukan sebagai bagian dari upaya memahami ketatanegaraan Indonesia modern serta mengenali identitas bangsa Indonesia yang senantiasa tumbuh dan berkembang dalam keberagaman. Salah satu hal yang menarik dari pelaksanaan hukum adat, yang selanjutnya disebut dengan Hukum Tata Negara Adat adalah mengenai pelaksanaan sistem demokrasi pada pengisian jabatan atau pemimpin adat dalam masyarakat hukum adat itu sendiri. Di dalam sistem demokrasi, pengisian jabatan atau pemimpin publik selalu di hubungkan dengan pelibatan rakyat secara aktif dan menyeluruh, dan pembukaan ruang bagi partisipasi publik dalam penyelenggaraan negara adalah inti dasar dari negara demokrasi. $^{7}$

Di antara sejumlah daerah yang pernah memiliki sistem pemerintahan dalam bentuk kerajaan adalah Kabupaten Konawe. Di masa lalu, wilayah ini pernah memiliki sebuah sistem kerajaan yang disebut kerajaan Konawe. Kerajaan ini didirikan oleh orang Tolaki yang bermukim di wilayah ini. Beberapa sumber sejarah menyebutkan bahwa suku Tolaki merupakan suku pendatang yang berasal dari daratan Tiongkok. Sekelompok masyarakat yang kemudian disebut suku Tolaki melakukan migrasi besar-besaran melalui danau Towuti dan Matana di Sulawesi Tengah kemudian menggeser penduduk lokal, suku Moronene, dan selanjutnya menetap di dataran Konawe. Beberapa sumber sejarah juga menyebutkan bahwa suku Tolaki memiliki kedekatan genealogis dengan beberapa etnis lain, seperti To raja, To mori, To Bungku, To kaili dan sebagainya. Hal ini dibuktikan dengan adanya beberapa kesamaan dalam bahasa, kepercayaan, tradisi dan perilaku hidup. ${ }^{8}$

Migrasi suku Tolaki dalam skala masif di daratan Konawe selanjutnya membentuk kesatuan-kesatuan kelompok yang terdiri dari beberapa Wonua (kampung) yang dipimpin oleh Toono Motuo (tetua atau yang dituakan). Beberapa Wonua yang dipimpin oleh Toono Motuo ini kemudian diintegrasikan ke dalam sistem kerajaan, yakni kerajaan Konawe, khususnya ketika raja (Mokole) perempuan berkuasa yakni We Tenriabeng atau We Koila. Wekoila merupakan mokole yang berhasil meletakkan dasar-dasar pemerintahan

7 Moh. Fadli, dkk, Pembentukan Peraturan Desa Partisipatif (Head To A Good Village Governance), Malang: UB Press, 2011, hlm. 89.

8 P. Sarasin dan F. Sarasin, 'Reise von der Mingkoka-Bai nach Kendari, Sudost Celebes' dalam Reisen in Celebes, Wiesbaden, 1905; A.C Kruijt dan J. Kruijt, 'Reise naar Kolaka' dalam TNAG, XXXVIII. 1921. ; A.C. Kruijt, 'Een en ander over de Tolaki van Mekongga', dalam Tijd., LXI. 1922; F. Treffers, 'Drie verhalen afkomstig van de Tolaki', dalam Tijd., L.V. 1913. 
'modern' dengan memanfaatkan sumber daya yang ada di beberapa wonua. Di masa pemerintahan Wekoila, Wonua tetap diakui eksistensinya dan diberikan kewenangan untuk mengatur wilayahnya masing-masing.

Pada masa pemerintahan Mokole Tebawo atau Sangia Inato, mulai disusun dewan adat atau yang disebut Pitu Dula Batu (tujuh dulang batu). Pitu Dula Batu ini terdiri dari tujuh orang menteri. ${ }^{9}$ Dalam rangka mengintegrasikan beberapa wilayah dan selanjutnya mempertahankan kerajaan dari infiltrasi, maka Sangia Inato menetapkan beberapa wilayah sebagai kerajaan-kerajaan kecil penyangga pusat kerajaan Konawe. Kerajaankerajaan penyangga ini disebut Siwole Mbatohu (empat talang) yang terdiri dari Barata $i$ Hana (sayap kanan), Barata i Moeri (sayap kiri), tambo i losoano oleo (pintu gerbang matahari terbit) dan Tambo i Tepuli, ano Oleo (pintu gerbang matahari terbenam). Penentuan wilayah kerajaan penyangga ini dimaksudkan, antara lain, untuk menyangga pusat kerajaan dan pengembangan wilayah.

Penempatan wilayah tersebut sangat strategis untuk dikontekstualisasikan saat ini. Paling tidak, sistem pembagian kekuasaan dengan penempatan wilayah Siwole Mbatohu layak diinterpretasikan dan direkonstruksi dalam rangka memberikan sumbangan pemikiran ketatanegaraan di Indonesia. Selain itu, konsep Siwole Mbatohu bisa dipahami sebagai bentuk kesatuan, dan harmoni antara kerajaan Konawe sebagai pusat (center) dan kerajaan penyangga sebagai pinggir (pheriphery).

Siwole Mbatohu sebagai sebuah konsep politik di kerajaan Konawe abad ke XVII perlu ditelaah lebih mendalam, khususnya dengan memanfaatkan telaah filosofis khususnya aspek epistemologi. Telaah epistemologi diperlukan dalam rangka menguak akar-akar kesejarahan, kebenaran atau validitas dan orisinalitas konsep itu. Langkahlangka kerja epistemologi akan dilakukan pada pembahasan selanjutnya. Atas dasar itu, tulisan ini hendak menjawab beberapa permasalahan, antara lain: apakah makna falsafah Siwole Mbatohu sebagai ekspresi politik di Kerajaan Konawe abad ke XVII? Bagaimana memahami falsafah Siwole Mbatohu dalam konteks relasi kuasa-pengetahuan dan perspektif epistemologi?

9 J.Vonk, Verstelg von Sangia Inato dochter von wasangguni \& Tawe Niroekoe. 1928. 


\section{ANALISIS DAN PEMBAHASAN}

\section{Relasi Kuasa-Pengetahuan}

Micahel Foucault dalam Power/Knowledge menyajikan sebuah konsep epistemologi dengan menekankan hubungan-hubungan antara pengetahuan dan kekuasaan. Foucault berpendapat ${ }^{10}$ :

...truth isn't outside power, or lacking in power... truth isn't the reward of free spirits...

Truth is a thing of this world. Each society has its regime of truth: that is, the types of discourse which it accepts and makes function as true...

Menurut Foucault,11 dalam masyarakat seperti (masyarakat) kita, "ekonomi politik" truth dikarakterisasikan oleh empat hal. Pertama, "truth" berpusat pada bentuk diskursus ilmiah dan institusi-institusi yang menghasilkannya. Kedua, ia merupakan subjek bagi dorongan ekonomi dan politik yang konstan. Ketiga, ia adalah objek, dalam bentuknya yang beragam. Keempat, ia dihasilkan dan ditransmisikan di bawah kendali aparat ekonomi dan politik tertentu. Terakhir, ia adalah isu dari keseluruhan debat politik dan konfrontasi sosial.

Haryatmoko,12 dengan mengutip Michael Foucault, dalam makalahnya yang berjudul “Kekuasaan-Pengetahuan Sebagai Rezim Wacana Sejarah Seksualitas: Sejarah Pewacanaan Seks \& Kekuasaan Menurut Foucault", mengemukakan bahwa dengan menekankan sejarah instansi-instansi produksi kekuasaan, Foucault tidak memisahkan pengetahuan-kekuasaan. Penelitiannya tentang subyek modern melalui bentuk-bentuk pengetahuan, praktik dan wacana terfokus pada kekuasaan-pengetahuan. Pendekatannya ini tidak jauh dari pemikiran Nietzsche yang menyebutkan bahwa semua keinginan untuk mengetahui kebenaran sudah merupakan bentuk keinginan akan kekuasaan. Semakin Foucault menggali pengetahuan praktis tentang subyek dan kekuasaan, semakin kelihatan bahwa konsepsi kekuasaan lebih mengarah ke subyektivasi dari pada obyektivasi kekuasaan, artinya bahwa "saya sebagai alat kekuasaan, lebih dipahami sebagai hasil dari

10 Michael Foucault, Power/Knowledge (Selected Interviews and Other Writings 1972-1977). Sussex: The Harvester Press, 1980, hlm. 131.

11 Ibid, hlm. 131-132.

12 Haryatmoko, "Kekuasaan-Pengetahuan Sebagai Rezim Wacana Sejarah Seksualitas: Sejarah Pewacanaan Seks \& Kekuasaan Menurut Foucault" Makalah Seri Kuliah Umum Juni 2010, makalah Disampaikan dalam Seri Kuliah Umum "Tentang Seksualitas" di Komunitas Salihara, Sabtu 12 Juni 2010. Lihat juga, J.G.Merquior, Foucault ou le nihilisme de la chaire, Paris: PUF, 1985, hlm. 128. 
dominasi dari pada sebagai sarana atau alat kebebasan individual". Persoalan ini mengandaikan pendefinisian kembali konsep kekuasaan.

Foucault mendefinisikan strategi kekuasaan sebagai yang melekat pada kehendak untuk mengetahui. Melalui wacana, kehendak untuk mengetahui terumus dalam pengetahuan. Bahasa menjadi alat untuk mengartikulasikan kekuasaan pada saat kekuasaan harus mengambil bentuk pengetahuan karena ilmu-ilmu terumus dalam bentuk pernyataan-pernyataan. Kekuasaan pengetahuan terkonsentrasi di dalam kebenaran pernyataan-pernyataan ilmiah.

Oleh karena itu semua masyarakat berusaha menyalurkan, mengontrol dan mengatur wacana mereka agar sesuai dengan tuntutan ilmiah. Wacana macam ini dianggap mempunyai otoritas. Pengetahuan tidak bersumber pada subyek, tetapi dalam hubungan-hubungan kekuasaan. "Kekuasaan menghasilkan pengetahuan. Kekuasaan dan pengetahuan saling terkait. tidak ada hubungan kekuasaan tanpa pembentukan yang terkait dengan bidang pengetahuan, dan tidak ada pengetahuan yang tidak mengandaikan serta tidak membentuk sekaligus hubungan kekuasaan".

Semua pengetahuan adalah politik, karena syarat-syarat kemungkinannya bersumber pada hubungan-hubungan kekuasaan. Anatomi politik menunjukkan bahwa teknik kekuasaan, produksi dan pengetahuan lahir dari sumber yang sama. Memang anatomi politik itu tidak menciptakan pengetahuan, tetapi genealogi. Dengan metode genealogi ditunjukkan bahwa kebenaran yang mengambil bentuk obyektivitas ilmu itu hanya ilusi. Metode yang sama memperlihatkan bahwa kehendak untuk tahu menjadi proses dominasi terhadap manusia. Setiap pengetahuan terkait dengan obyek kekuasaan seperti orang gila, kriminal, anak remaja, orang sakit, atau buruh. Kaitannya terletak pada kemampuan pengetahuan mendefinisikan realitas obyek tersebut. Dengan mendefinisikan realitas, akibatnya pengetahuan mengubah konstelasi sosial.

Foucault mengatakan dengan kekuasaan "harus dipahami pertama-tama banyak dan beragamnya hubungan-hubungan kekuatan yang melekat pada bidang hubunganhubungan tersebut dan organisasinya. Permainannya akan mengubah, memperkuat, membalikkan hubungan-hubungan itu melalui perjuangan dan pertarungan terusmenerus". 13

13 M. Foucault, Histoire de la sexualité I. La volonté du savoir, Paris: Gallimard, 1976, hlm. 121-122. 
Kekuasaan berarti menempatkan konflik dalam berbagai institusi sosial, dalam ketidaksetaraan ekonomi, dalam bahasa, dan bahkan dalam tubuh kita masing-masing. Foucault mencoba mendefinisikan kembali kekuasaan dengan menunjukkan ciri-cirinya: kekuasaan tidak dapat dilokalisasi, merupakan tatanan disiplin dan dihubungkan dengan jaringan, memberi struktur kegiatan-kegiatan, tidak represif tetapi produktif, serta melekat pada kehendak untuk mengetahui.

Menurut Foucault, ada lima cara bagaimana kekuasaan beroperasi. ${ }^{14}$ Pertama, kekuasaan tidak diperoleh, diambil atau dibagikan, kekuasaan berjalan dari berbagai titik, dalam permainan hubungan yang tidak setara dan selalu bergerak. Kedua, kekuasaan itu cair karena di mana ada perbedaan terbuka hubungan kekuasaan. Hubungan kekuasaan adalah imanen, artinya hubungan kekuasaan adalah efek langsung dari pembagian, perbedaan, ketidaksetaraan dan ketidakseimbangan. Ketiga, hubungan kekuasaan tidak berada dalam posisi suprastruktur. Kekuasaan datang dari bawah, artinya tidak ada oposisi biner antara yang didominasi dan yang dominan. Hubungan-hubungan kekuatan itu banyak dan terbentuk serta bermain di dalam aparat produksi seperti di keluarga, kelompok, institusi, keseluruhan tubuh sosial. Ke empat, hubungan kekuasaan itu intensional. Tidak ada kekuasaan tanpa serangkaian sasaran. Rasionalitas kekuasaan adalah taktik yang tersurat pada tingkat terbatas.

Orang bisa memahami hubungan kekuasaan dalam kerangka tujuan dan sasaran. Tujuan dan sasaran ini tidak dimiliki oleh individu atau suatu kelas, tetapi dalam bentuk anonim, hasil dari situasi-situasi lokal. Strategi adalah anonim bukan kenyataan subyek. Foucault menempatkan wacana tentang seks bukan dalam kerangka kekuasaan tunggal dan sentral yang menindas atau sistem hukum kedaulatan, tetapi dalam hubunganhubungan kekuasaan yang sekaligus banyak dan selalu bergerak.

Kelima, di mana ada afirmasi kekuasaan, di situ ada resistensi. Resistensi ini bukan berasal dari posisi di luar hubungan kekuasaan. Perlawanan menjadi bagian dari kekuasaan itu sendiri. Kekuasaan melahirkan anti-kekuasaan. Di mana ada afirmasi kekuasaan selalu ada perlawanan, bukan dalam arti kekuatan dari luar atau yang berlawanan, tetapi karena adanya kekuasaan itu sendiri.

\section{Kebenaran Pengetahuan}

14 Ibid., hlm. 124-125. 
Epistemologi membicarakan antara lain hakikat pengetahuan, yaitu apa pengetahuan itu sesungguhnya. Juga membicarakan sumber pengetahuan dan bagaimana cara memperoleh pengetahuan. Runes sebagaimana dikutip oleh Tafsir menjelaskan bahwa epistemology is the branch of philosophy which investigates the origin, structure, methods and validity of knowledge (epistemologi adalah cabang filsafat yang menginvestigasi asal mula, struktur, metode dan validitas pengetahuan). Di dalam Routledge Encyclopedia of Philosophy dikemukakan bahwa epistemologi mencoba menjawab pertanyaanpertanyaan: (1) apa itu pengetahuan-apakah analisis yang benar itu atau definisi konsep pengetahuan?(2) bagaimana keluasan pengetahuan kita - mengenai apakah jenis-jenis pengetahuan yang benar-benar dimiliki? (3) apakah sumber-sumber pengetahuan itubagaimana pengetahuan itu diperoleh? dan (4) adakah pengetahuan yang sejati?15

Diskursus epistemologi biasanya selalu terkait dengan upaya mencari, menguak dan membuktikan kebenaran pengetahuan. Pengetahuan lahir dari aktivitas subjek yang sadar terhadap semua informasi yang masuk dalam diri subjek atau yang dikenal dan ingin dikenal oleh subjek. Pengetahuan yang lahir di dalam dirinya sudah terdapat kebenaran, dan memang setiap pengetahuan yang di kuak oleh seseorang di dalamnya telah terkandung kebenaran. Hospers menyatakan pengetahuan mesti benar. Jadi isi pengetahuan selalu benar, atau dengan kata lain pengetahuan adalah pengetahuan yang benar. Kesalahan terjadi dan hanya terjadi karena informasi yang diterima melalui otoritas sudah mengandung kesalahan-misalnya, informasi dari orang tua tidak lengkap, dari guru kurang memadai, dari pejabat tidak sesuai dengan fakta, dan lain-lain-atau, indera subjek tidak normal — misalnya buta warna, gangguan pendengaran dan lain-lain-. Atau, penalaran seseorang itu tidak mengikuti norma-norma logika yang benar — tidak mengikuti hukum penyimpulan logika, dan aturan berpikir runtut lainnya. ${ }^{16}$

Terjadinya pengetahuan dapat karena aktivitas indera, rasio, intuisi, atau keyakinan, serta dari revelasi atau melalui otoritas seseorang. Atau, dapat juga karena subjek sangat terikat pada objek (Empiristik), atau objek yang masuk atau diandaikan ada dalam kesadaran subjek (Rasionalistik), atau menempatkan keseimbangan antara subjek dan objek (Fenomenalisme dan Fenomenologi). Masing-masing cara memperoleh pengetahuan itu memerlukan cara pembuktian kebenaran yang berbeda pula.

15 Ahmad Tafsir, Filsafat Umum: Akal dan Hati Sejak Thales sampai James. Bandung: PT. Remaja Rosdakarya, 1994, hlm. 21.

16 J. Hospers, An Introduction to Philosophical Analysis, Englewood Cliffs: Prentice-Hall, 1967. 
Analisa epistemologi SM dapat memanfaatkan beberapa teori kebenaran pengetahuan. Mintaredja ${ }^{17}$ mengemukakan beberapa teori kebenaran, antara lain adalah:

\section{Teori Kebenaran Korespondensi}

Teori ini dikenal sebagai salah satu teori kebenaran tradisional atau teori yang paling tua. ${ }^{18}$ Teori ini bertolak dari pernyataan Aristoteles yaitu "..... to say of what is that it is or of what is not that it is not, is true". Menurut teori ini pengetahuan benar adalah pengetahuan dengan berdasar pada asas logis bahwa ".... that it is true that $p$, if and only if $p$ ". Sehingga, menurut teori korespondensi ini sebagaimana dikemukakan White ${ }^{19}$ bahwa “.... since $p$ is true if and only it $p$, then when what is said e.g. $p$ is true'. Pernyataan ini mengikuti filsafat Moore $^{20}$ bahwa pengetahuan terjadi karena adanya pemahaman langsung terhadap objek (direct apprehension), maka pengetahuan tentang objek tertentu mesti dipercaya keberadaan dan kebenarannya. Hal demikian disetujui pula oleh Marhenke bahwa “.... to see a physical object is to see”. ${ }^{21}$. Moore secara tegas menjelaskan bahwa Pengetahuan benar manakala cerapan indera atau data indera memiliki hubungan dan saling berkesesuaian (correspondence) dengan objek atau benda-benda material. ${ }^{22}$

Uraian di atas dapat disimpulkan bahwa, pengetahuan atau yang tercermin dalam proposisi yang benar dapat dibuktikan langsung pada fakta atau objek yang diinderai, atau yang dapat dijabarkan langsung pada dunia empirik atau pengalaman langsung yang dapat diamati indera. Pengetahuan inderawi atau pengetahuan yang berdasar pada pengalaman indera kebenarannya dapat dibuktikan dengan mengacu pada objek pengetahuan itu. Kekhilafan atau kesalahan dapat terjadi karena kesalahan penginderaan atau kurang cermatnya menginderai dan atau indera sudah tidak normal.

17 Abbas Hamami Mintaredja, Abbas Hamami. Kebenaran; Suatu problema filsafat pengetahuan. Bahan kuliah. Yogyakarta: Fakultas Filsafat UGM, 2009.

18 R.F.A. Hornie, 1952, Studies in Philosophy, George Allen\&Unwin Ltd, London 1952). Hornie menyatakan secara jelas bahwa "... it affirms that our thoughts or ideas are true or false according as they agree (correspond), or do not agree, with a fact such as I think it to be". Hal demikian juga sesuai dengan pendapat Kattsoff yang menyatakan bahwa, kebenaran atau keadaan benar berupa kesesuaian (correspondence) antara makna yang dimaksud oleh suatu pernyataan dengan yang sungguh-sungguh merupakan halnya atau apa yang merupakan faktanya (fakta yang actual being). Lihat Louis 0. Kattsof, Pengantar Filsafat. Yogyakarta: Tiara Wacana, 1986.

19 A.R. White, Truth; Problem in Philosophy, New York: Doubleday \& Co, 1970.

20 G.E. Moore, Some Main Problems of Philosophy London: George, Allen and Unwin, 1953.

21 P. Marhenke "Moore's Analysis of Sense-Perception" dalam Schlipp, Logical Positivism, 1953.

22 Moore menyatakan, "When the belief is true, it certainly does correspond to a fact, and when it corresponds to a fact it certanily true. And similarly when it is false, it certainly does not correspond to any fact; and when it does not correspond to any fact, then certainly false". G.E. Moore, Some Main Problems of Philosophy London: George, Allen and Unwin, 1953. 


\section{Teori Kebenaran Koherensi}

Teori ini dibangun oleh para epistemologi yang bertolak pada sikap ontologis bahwa objek berupa hal abstrak sehingga diandaikan ia hadir dalam kesadaran subjek. Paham ini dianut pula oleh mereka yang mengembangkan paham logika positivisme. Menurut teori ini bahwa

"....to say that what is said (ussually called judment, belief, or proposition) is true or false is to say that it cohere with a system of other thing which are said; that it is a member of a system whose elements are related to each other by ties of logical implication as the element in a system of pure mathematics are related' ${ }^{23}$

Dapat dikemukakan juga bahwa proposisi bernilai benar bila proposisi itu mempunyai hubungan dengan ide-ide atau gagasan-gagasan dari proposisi terdahulu yang bernilai benar dalam suatu sistem pemikiran yang saling berhubungan secara logiksistematik. Sebagai contoh jika kita ingin membuktikan bahwa runtuhnya Majapahit pada tahun 1478 atau 1400 Çaka dengan candra sangkala Sirna Ilang Kertaning Bumi, ${ }^{24}$ maka dalam pembuktian kebenaran itu kita tak dapat melihat langsung seperti para epistemolog realis tetapi harus melalui proposisi-proposisi terdahulu yang mewartakan tentang runtuhnya Majapahit. Proposisi itu dapat ditemukan dalam catatan sejarah atau catatan lain yang menguak kejadian itu. Dengan demikian, kebenaran pengetahuan itu dapat diuji melalui kejadian-kejadian sejarah atau data-data sejarah yang dapat dipertanggungjawabkan.

\section{Teori Kebenaran Konsensus}

Teori ini dikembangkan oleh Jurgen Habermas. Kriteria kebenaran menurut teori ini adalah persepakatan atau persetujuan yang dianggap rasional dari suatu perbincangan tertentu. Oleh karena itu, kebenaran yang berdasarkan konsensus tidak dapat berlaku mutlak satu kali perbincangan untuk selamanya, sebab hasil perbincangan mana pun harus terbuka untuk diperbincangkan kembali.

Untuk dapat sampai pada suatu kebenaran yang bersifat kesepakatan atau konsensus harus dipenuhi syarat-syarat situasi perbincangan yang ideal. Untuk menghindarkan kesulitan yang mungkin timbul peserta perbincangan harus

23 A.R. White, Truth; Problem in Philosophy, New York: Doubleday\&Co, 1970.

24 Istilah "candra sangkala Sirna Ilang Kertaning Bumi” Berarti HILANG Lenyap Ditelan Bumi, Begitu Kita Bisa Memaknai Ungkapan 'Sirna Ilang Kertaning Bumi'. Ungkapan Ini Sekaligus Menandakan Tahun Keruntuhan Majapahit, 1400 Saka Atau 1478 Masehi. 
mengandaikan bahwa yang diperbincangkan situasi empiris yang aktual (dalam bahasa Aristoteles yang actual being/factual). Syarat-syarat yang harus dipenuhi antara lain adalah (1) Semua peserta perbincangan harus diberi kesempatan yang sama untuk bicara seperti apa yang diinginkannya. (2) Peserta diberi kesempatan yang sama untuk menafsirkan, menganjurkan, membenarkan, dan juga mempersoalkannya, (3) Semua peserta dituntut agar mengambil sikap komunikatif yang wajar yakni mengutarakan apa yang dipikirkannya dan betul-betul bermaksud menyampaikan pikiran-pikirannya kepada peserta lain; Dan, (4) Di antara peserta perbincangan tidak dibolehkan ada perbedaan wewenang atau kekuasaan yang dapat mempengaruhi jalannya perbincangan ${ }^{25}$

Teori kebenaran konsensus ini pada tataran filsafat politik menjadi basis bagi teori demokrasi pada saat melakukan perbincangan politik. Dengan demikian, tak ada jarak di antara peserta perbincangan dan hasilnya dapat dikoreksi atau disaksikan bersama dengan tidak memper-hatikan sekat ideologi, jabatan, atau lainnya, karena setiap hasil perbincangan disampaikan secara terbuka kepada publik pada ruang publik yang terbuka.

\section{Epistemologi Politik kewilayahan Siwole Mbatohu}

Berbeda dengan beberapa etnis di Indonesia, khususnya di jazirah Sulawesi yang memiliki aksara dan bahasa tulis, misalnya di Sulawesi Selatan dengan Lontarak sebagai sumber primer dalam pengkajian sejarah dan kebudayaan Sulawesi Selatan, ${ }^{26}$ suku Tolaki tidak memiliki tradisi tulisan. Karena itu, informasi tentang keberadaan kerajaan Konawe dengan segala bentuk varian-variannya hanya didapatkan dari sumber-sumber lisan dan laporan-laporan berbahasa Belanda dan sumber-sumber Bugis. Maka, upaya mengungkap sejarah dan kebudayaan Tolaki didasarkan dari tuturan atau wawancara lisan dengan tokoh-tokoh masyarakat dan adat yang memiliki pengetahuan mendalam tentang hal tersebut. Dengan kata lain, sumber-sumber lisan menjadi sumber primer, sementara sumber-sumber tertulis menjadi sumber sekunder dalam rangka mendukung sumber primer tersebut. Karena itu, transmisi pengetahuan budaya Tolaki menemukan ruangnya

25 Jurgen Habermas, The Theory of Communicative Action, volume 2, System and Lifeworld: A Critique of Functionalist Reason. Boston, MA: Beacon Press, 1987; F. Budi Hardiman, Fransisco Budi, 1990. Kritik Ideologi: Pertautan Pengetahuan dan Kepentingan, Yogyakarta: penerbit Kanisius.1990; F. Budi Hardiman, Demokrasi Deliberatif: Menimbang 'Negara Hukum' dan 'Ruang Publik' dalam Teori Diskursus Jurgen Habermas, Yogyakarta: Penerbit Kanisius, 2009.

26 J. Noorduyn,"Origins of South Celebes Historical Writing" dalam Soedjatmoko et al.,(ed.), An Introduction to Indonesian Historiography. $3^{\text {th }}$ edition. Ithaca and London: Cornell University Press, 1975; Andi Zainal Abidin, "Notes on the Lontara' as Historical Sources". Indonesia, No. 12 (Oktober), Ithaca, New York: Cornell Modern Indonesia Project, 1971. 
melalui cerita-cerita dari tokoh-tokoh elit dalam masyarakat Tolaki. Peran tokoh-tokoh tertentu, dalam hal ini elit tertentu dalam proses transmisi pengetahuan budaya Tolaki dinilai cukup signifikan. Dalam masyarakat Tolaki, cerita-cerita dari leluhur dan orangorang tua memegang peran penting dalam proses pemberian pengetahuan dan informasi mengenai budaya Tolaki, serta pelanjut dan penjaga kontinuitas tradisi dan budaya Tolaki. Selain itu, melalui media pendidikan formal, diyakini merupakan salah satu alat paling signifikan dalam proses transmisi kultural ini. Terkait dengan hal ini, Anthony Giddens menyatakan

"The transmission of cultural values and norms from generation to generation. Cultural reproduction refers to the mechanism by which continuity of cultural experience is sustained across time. Cultural reproduction occurs in a more profound way through the hidden curriculum-aspects of behavior which individuals learn in an informal way while at school". ${ }^{27}$

Berdasarkan pertimbangan tersebut, maka sebagian informasi mengenai kebudayaan Tolaki didapatkan melalui proses wawancara. Wawancara adalah dasar bagi semua penelitian lisan. Hal itu bisa berupa wawancara naratif, wawancara elite, wawancara kelompok, wawancara pengalaman hidup-yang berarti merupakan diskursus antara dua orang atau lebih mengenai sebuah masalah, sejumlah masalah atau pertukaran informasi terbuka atau tertutup. Tentu saja hal itu berarti lebih dari sekedar wawancara untuk suatu pekerjaan atau pertukaran informasi secara sambil lalu. Penelitian lisan dengan metode wawancara akan sangat efektif, bila dilangsungkan dalam suatu dialog antara dua orang tertentu-pewawancara dan informan (atau orang yang diwawancarai). Pewawancara harus berpengetahuan luas dan siap memperoleh semua informasi yang harus diberikan oleh informan. Pewawancara harus juga mahir dalam mengorek informasi yang tidak dapat diberikan oleh informan tanpa mengganggu alur wacana. Makna penelitian lisan yang terkait dengan sejarah bisa berkurang, bila pewawancara tidak memahami masalah. Bila pewawancara belum membaca sumbersumber yang relevan, menganalisis sumber primer dan mempertimbangkan dengan seksama pertanyaan-pertanyaan serta jawaban-jawaban yang dapat diterimanya, maka informan tidak akan berfungsi secara maksimal, dan karena itu, informasi yang diperoleh tidak bermutu tinggi. 28

27 Anthony Giddens, Sociology. UK: Polity Press, 1997.

28 James Morrison, "Perspektif Global Sejarah Lisan Asia Tenggara". Dalam P. Lim Pui Huen, James H. Morrison, dan Kwa Chong Guan. Sejarah Lisan Asia Tenggara: Teori dan Metode. Jakarta: LP3ES Indonesia, 
Pemahaman dan validitas tentang sejarah dan falsafah kebudayaan suku Tolaki, khususnya yang terkait dengan Siwole Mbatohu, dapat dilakukan dengan memanfaatkan hermeneutika Dilthey. Dilthey menulis bahwa realitas bagi kita berada dalam kenyataan yang disadari yang ditentukan oleh pengalaman internal. pengalaman terbentuk dengan cara melihat dan menafsirkan peristiwa melalui kesadaran, dan dengan demikian menjadi bagian integral dari pengertian, kesadaran, perasaan, dan harapan. ${ }^{29}$

Menurut Dilthey, kesulitan dalam menghadapi pengalaman bisa diatasi kalau kita “mengatasi lingkup yang terbatas dari pengalaman dengan cara menafsirkan ungkapan. Dengan kata lain, mendengarkan apa yang dikatakan orang lain, dalam kata-kata, gambaran, dan tindakan mereka mengenai hidup mereka. Ungkapan memang mencakup banyak hal. Ungkapan ditampilkan pada kita sebagai cerita-cerita mengenai kehidupan, atau narasi, memoar, etnografi, karya sastra, pertunjukan, teater, ritual, parade, karnaval atau bentuk-bentuk representasi dan kristalisasi lain dari pengalaman manusia. Bentukbentuk ungkapan yang berbeda-beda itu mengenai ungkapan atau representasi pengalaman manusia merupakan "teks" yang memungkinkan kita memahami diri kita sendiri dan orang lain. ${ }^{30}$

Upaya mengukur manfaat dari penelitian lisan di bagian dunia mana pun adalah menerapkan tolok ukur yang digunakan seorang peneliti, apakah itu sejarawan, ahli antropologi, ahli folklor, pada apa yang telah mereka pelajari. Metodologi wawancara, analisis teks dan sub teks dari catatan, serta membandingkan dengan hasil penelitian lisan lain, semuanya penting. Seperti yang telah disebutkan di atas, ada tiga saringan atas masa lampau dalam penelitian lisan: (1) masa lampau seperti dilihat oleh informan: (2) masa lampau seperti yang didengar dan diinterpretasi oleh informan: (3) masa lampau seperti yang dipahami oleh yang mendengar pita rekaman. ${ }^{31}$.

Beberapa sumber sejarah tertulis menyebutkan bahwa istilah Siwole Mbatohu merupakan ekspresi politik kewilayahan pada masa kepemimpinan Mokole Tebawo atau Sangia Inato pada abad ke XVII. Dokumentasi DPRD Tingkat I Sulawesi Tenggara32

2000. hlm. 3-4. Bandingkan dengan, Reiza D. Dienaputra, Sejarah Lisan: Metode Dan Praktek, Bandung: Penerbit Balatin, 2013.

29 William Dilthey, Dilthey: Selected writings, diedit oleh H.P Rickman, Cambridge: Cambridge University Press, 1976, hlm. 161.

30 William Dilthey, Dilthey: Selected writings, diedit oleh H.P Rickman, Cambridge: Cambridge University Press, 1976, hlm. 230. Lihat juga Yos Santasombat, "Sejarah Lisan dan Potret Diri" dalam P. Lim Pui Huen et. Al (ed.), Sejarah Lisan di Asia Tenggara: Teori dan Metode." Jakarta: LP3ES, 2000, hlm. 128.

31 Morrison, Op. Cit., hlm 31-32.

32 Abdurrauf Tarimana dkk, Dokumenta Historica DPRD TK I Sulawesi Tenggara. Kendari, 1987. 
menyebutkan bahwa struktur pemerintahan Mokole Tebawo (Sangia Inato) disusun berdasarkan sistem Siwole Mbatohu dan Pitu Dula Batu. Siwole Mbatohu merupakan kekuasaan wilayah kerajaan yang dibagi atas:

a. Wilayah bagian barat kerajaan Konawe yang disebut Tambo i Tepuli, ano Oleo yang berkedudukan di Latoma dipimpin oleh Sabandara;

b. Wilayah bagian Timur kerajaan Konawe yang disebut tambo i Losoano Oleo berkedudukan di Ranomeeto yang dipimpin oleh Sapati;

c. Wilayah bagian Kanan (Utara) kerajaan Konawe yang disebut Bharata i Hanano Wuta Konawe yang berkedudukan di Tongauna dipimpin oleh Ponggawa;

d. Wilayah bagian kiri (Selatan) kerajaan Konawe yang disebut Bharata i Moerino Wuta Konawe berkedudukan di Asaki yang dipimpin Inowa.

Pengibaratan Kerajaan Konawe sebagai suatu Siwole yang bersudut empat dapat dilihat adanya pembagian empat wilayah kepemerintahan atau pemberian semacam otonomi kepada wilayah-wilayah tersebut. Ditinjau dari segi nama kesatuan wilayah Tambo dan Bharata yang berarti gerbang dan sayap, di dalamnya terkandung pengertian otonomitas dan unsur pertahanan dan kepentingan perekonomian. ${ }^{33}$

Selain itu, dalam menjalankan pemerintahan Mokole Tebawo mengangkat beberapa pejabat kerajaan atau dewan adat yang disebut Pitu Dula Batu yang terdiri dari: (1) aparat keamanan yang disebut Tutuwi Motaha, rambaha monggasono o Una, Polapi wunggu, arono wuta Konawe (bendera merah, batu asah negeri Una yang tajam, benteng pertahanan kerajaan Konawe), yang dijabat oleh seorang raja yang bergelar anakia ndamalaki, yang berkedudukan di Anggaberi; (2) aparat pertanian yang disebut Tusa Wuta, rome romeno wuta Konawe (tiang pusat tanah, sumber kemakmuran rakyat Konawe) yang dijabat oleh seorang raja yang bergelar Anakia Ndusawuta yang berkedudukan di Kasupute; (3) aparat peradilan adat yang disebut bite kinalumbi (pohon siri yang kokoh dan membelit) dijabat oleh seorang raja bergelar Anakia Kinalumbi, berkedudukan di Kasupute; (4) kotubitara (pemutus perkara) yang dijabat Anakia

33 Bhurhanuddin dkk, Sejarah kebangkitan Nasional Daerah Sulawesi Tenggara. Jakarta: Departemen Pendidikan dan Kebudayaan Pusat Penelitian Sejarh dan Budaya Proyek Penelitian dan pencatatan Kebudayaan Daerah. 1978/1979; Asrul Tawulo dkk, Pranata Kepemimpinan Tusa wuta dalam Sistem Pertanian Masyarakat Tolaki di Kabupaten Kendari. Laporan Penelitian. Kendari: Balai Penelitian Universitas Haluoleo, 1991/1992; Muslimin Su'ud, Peranan Kepemimpinan kelembagaan Adat Kalosara dalam Pembinaan Tertib Sosial dan tertib Hukum untuk Meningkatkan partisipasi Masyarakat terhadap pembangunan masyarakat Pedesaan di kabupaten daerah Tingkat II kendari Laporan Penelitian. Kendari: Balai Penelitian Universitas Haluoleo, 1992; Abdurrauf Tarimana, Kebudayaan Tolaki. Jakarta: Balai Pustaka, 1993. 
Mbabitara berkedudukan di Wonggeduku; (5) aparat penegak hukum yang disebut Petumbu lara dati (tiang agung rumah dari teras kayu jati) yang dijabat oleh Anakia Mbetumbu berkedudukan di Tudaone; (6) aparat kerukunan hidup yang disebut Bite Metado (daun sirih yang bertulang buku paralel) yang dijabat oleh Anakia Metado berkedudukan di Unaaha, dan (7) aparat mata-mata yang disebut Tusa Lara dati (tiang rumah dari teras kayu jati) dijabat oleh Anakia Ndusa Lara yang berkedudukan di Lalosabila. ${ }^{34}$

Berbeda halnya dengan Bhurhanuddin dkk. yang menyebutkan pitu dula batu sebagai kabinet kerajaan Konawe yang terdiri dari:

a. Sulemandara, Perdana menteri dan urusan luar negeri;

b. Kotubitara, urusan hukum/peradilan;

c. Anakia Mombonahuako, urusan rumah tangga istana;

d. Tusawuta, urusan pertanian;

e. Tutuwi Motaha, panglima/keamanan istana;

f. Kapita Anamolepo, pimpinan pemuda/keamanan di darat;

g. Kapitalau, urusan keamanan di laut. ${ }^{35}$

Berdasarkan uraian tersebut, maka wilayah kerajaan Konawe pada abad ke XVII terbagi atas: (1) empat wilayah Siwole Mbatohu; (2) tujuh wilayah Pitu dula Batu; (3) satu wilayah Inea Sinumo (putra mahkota, calon pengganti raja atau Mokole) yang berkedudukan di Abuki, dan (4) satu wilayah khusus di Andoolo. Selain hal tersebut, tiaptiap wilayah terbagi atas Tobu yang dikepalai oleh Puu Tobu. Menurut penuturan Husen A Chalik $^{36}$ jumlah Tobu seluruhnya adalah tiga puluh yang masing-masing lagi terbagi atas wilayah yang dipimpin Toono Motuo. Jumlah toono motuo adalah tiga ratus orang.

Penentuan wilayah di Kerajaan Konawe, menurut penulis, secara strategis dilakukan dalam rangka memperkuat ketahanan politik dan ekonomi kerajaan Konawe. Secara politis, Mokole Tebawo mengangkat keturunannya dalam jabatan-jabatan strategis pada empat wilayah kerajaan yang disebut Siwole Mbatohu. Dengan cara ini, Mokole Tebawo ingin mengintegrasikan seluruh wilayah yang ada ke dalam kerajaan Konawe. Meski demikian, integrasi wilayah-wilayah ini tidak menafikan aspek otonomi pada masing-masing wilayah. Kerajaan-kerajaan penyangga diberi kewenangan penuh untuk

34 Abdurrauf Tarimana, Kebudayaan Tolaki. Jakarta: Balai Pustaka, 1993.

35 Bhurhanuddin dkk, loc. Cit.

36 Dalam Bhurhanuddin dkk, ibid. 
memenuhi kebutuhan hidup masyarakatnya. Secara ekonomis, Siwole Mbatohu menempatkan keempat wilayah tersebut ke dalam posisi yang cukup strategis untuk pengembangan wilayah. Dengan dukungan sektor pertanian, maka keempat wilayah tersebut mampu mengelola sumber daya ekonominya.

\section{Siwole Mbatohu: Relasi Kuasa-Pengetahuan}

Dalam epistemologi Foucault, pengetahuan memproduksi kekuasaan. Segenap konsep, wacana dan pengetahuan memiliki relasi dengan kekuasaan. Pertautan antara pengetahuan dan kekuasaan ini mengandaikan bahwa pengetahuan diciptakan dalam rangka memproduksi kekuasaan. Wacana macam ini dianggap mempunyai otoritas. Menurut Foucault, ${ }^{37}$ Pengetahuan tidak bersumber pada subyek, tetapi dalam hubunganhubungan kekuasaan. "Kekuasaan menghasilkan pengetahuan. Kekuasaan dan pengetahuan saling terkait. tidak ada hubungan kekuasaan tanpa pembentukan yang terkait dengan bidang pengetahuan, dan tidak ada pengetahuan yang tidak mengandaikan serta tidak membentuk sekaligus hubungan kekuasaan".

Berpijak pada pandangan Foucault tersebut, pengetahuan diproduksi dalam rangka mengokohkan hubungan-hubungan kekuasaan. Atas dasar ini, Haryatmoko menyatakan bahwa Semua pengetahuan adalah politik karena syarat-syarat kemungkinannya bersumber pada hubungan-hubungan kekuasaan. Anatomi politik menunjukkan bahwa teknik kekuasaan, produksi dan pengetahuan lahir dari sumber yang sama. Memang anatomi politik itu tidak menciptakan pengetahuan, tetapi genealogi. Dengan metode genealogi ditunjukkan bahwa kebenaran yang mengambil bentuk obyektivitas ilmu itu hanya ilusi. Metode yang sama memperlihatkan bahwa kehendak untuk tahu menjadi proses dominasi terhadap manusia. Setiap pengetahuan terkait dengan obyek kekuasaan seperti orang gila, kriminal, anak remaja, orang sakit, atau buruh. Kaitannya terletak pada kemampuan pengetahuan mendefinisikan realitas obyek tersebut. Dengan mendefinisikan realitas, akibatnya pengetahuan mengubah konstelasi sosial. ${ }^{38}$

Kaitannya dengan SM, ia diproduksi dalam rangka melanggengkan status quo, mengokohkan kekuasaan, dan mengontrol kekuasaan pada empat wilayah kerajaan, yakni sayap dan gerbang. Relasi-relasi ini dibangun untuk mengabsahkan kekuasaan pusat kerajaan Konawe sebagai kesatuan genealogis yang memiliki keterkaitan dengan wilayah-

37 M. Foucault, Surveiller et punir. Naissance de la prison, Paris: Gallimard, 1975, hlm. 36.
38 Haryatmoko, loc. Cit. 
wilayah lain dalam SM. Penyebutan Mokole Tebawo, dan bahkan raja-raja Konawe praIslam sebagai sangia (dewa) mengisyaratkan bahwa mokole adalah pengejawantahan dewa-dewa, simbol kekuatan, tempat bersandar yang paling otoritatif bagi semua masyarakat di wilayah kerajaan Konawe. Dalam masyarakat Tolaki, Mokole sering kali digambarkan sebagai pu'uno o kasu (induk pohon, pohon besar) yang dapat dipahami sebagai pelindung rakyat, mohopulei wonua (membangun negeri) dalam arti seluruh wilayah dengan segala apa yang ada di atasnya. Selanjutnya, pengandaian mokole sebagai sangia, mataoleo (matahari), mata wula (bulan), dan ana wula (bintang gemintang) tampak dalam sapaan terhadap raja: "ie inggomiu ombu, mberiou sangia, mata oleo, mata wula, ana wula" (wahai engkau dewa yang disembah, sanghyang yang disanjung, moyang yang dipuja, matahari, bulan dan bintang-bintang yang ditinggikan.....). ${ }^{39}$

Relasi kuasa-pengetahuan yang terbangun dalam konsep SM memperlihatkan sebuah motif penciptaan konsep untuk mengontrol dan melanggengkan kekuasaan. Upaya pelanggengan kekuasaan, dan selanjutnya dalam rangka menjaga harmoni atau keseimbangan antara raja dengan rakyatnya, dengan mengangkat putra dan keturunan Mokole Tebawa menjadi raja bawahan di keempat wilayah tersebut. Dengan cara ini, kekuasaan akan tetap kokoh dan tidak terganggu oleh intrik-intrik politik, dan pemberontakan dari raja-raja bawahan.

\section{Validitas Konseptual Siwole Mbatohu}

Validitas konseptual SM dapat dianalisis dengan menggunakan beberapa teori kebenaran, seperti teori koherensi, korespondensi, konsensus, dan otoritarian. Pengujian kebenaran atas konsep SM merupakan langkah-langka kerja epistemologis yang pada prinsipnya hendak menguji kebenaran realitas kesejarahan dan ketersambungan konsep SM dengan konteks saat ini. Dengan mendalami laporan-laporan tertulis, wawancara mendalam serta pengecekan silang (crosscheck), dapat diketahui ketersambungan dan ketidaktersambungan (continuity dan discontinuity) SM dengan masa kini. Di samping itu, dengan memnafaatkan teori kebenaran konsensus dapat diketahui konsep SM sebagai hasil kesepakatan bersama antara Mokole atau raja dengan rakyatnya dan bagaimana 'suasana batin' ketika mokole beserta rakyatnya melakukan kontrak bersama (social contract) untuk menentukan bawah SM merupakan ekspresi politik yang paling layak

39 Abdurrauf Tarimana, op. cit., hlm. 188, 191-192. 
diterapkan di kerajaan Konawe abad ke XVII. Teori kebenaran otoritarian sesungguhnya ingin menguak aktor-aktor pemegang kebanaran otoritatif dalam SM.

Pada tataran teori korespondensi, pengetahuan dapat dianggap benar jika pengetahuan itu berdasar pada asas logis, pengetahuan terjadi karena adanya pemahaman langsung terhadap objek (direct apprehension). Karena itu, pengetahuan tentang objek tertentu mesti dipercaya keberadaan dan kebenarannya, Pengetahuan benar manakala cerapan indera atau data indera memiliki hubungan dan saling berkesesuaian (correspondence) dengan objek atau benda-benda material.

Teori korespondensi didasarkan pada pengalaman empiris. Jika hal ini diterapkan di dalam menguji validitas SM, maka peneliti harus melihat langsung obyek materi dari SM dan melakukan pengecekan silang dengan sumber-sumber tertulis. Langkah-langkah ini dapat dilakukan melalui observasi lapangan untuk melihat tinggalan-tinggalan arkeologis di keempat wilayah SM, mengecek kebenarannya melalui penelaahan sumber-sumber tertulis seperti factum atau perjanjian antara Mokole Tebawo dengan keempat raja bawahan di wilayah SM. Tinggalan-tinggalan arkeologis dan sumber tertulis dalam bentuk factum tersebut dapat juga dicek kebenarannya melalui wawancara lisan dengan sejumlah tokoh adat Tolaki dan orang-orang yang mempunyai hubungan genealogis secara langsung dengan raja/Mokole Tebawo dan raja-raja bawahan di keempat wilayah SM tersebut.

Sampai sejauh ini, belum ada penggalian arkeologis dalam skala masif terhadap reruntuhan keraton di kerajaan Konawe dan keempat wilayah SM. Bukti-bukti historis mengenai keberadaan kerajaan Konawe dapat ditemukan dan diketahui melalui situs-situs purbakala seperti makam raja terakhir di kerajaan Konawe yang bernama Raja Lakidende atau bergelar sangia Ngginoburu (dewa yang dikuburkan) dan kuburan istrinya, serta perangkat-perangkat kerajaan. Selain itu, keberadaan kerajaan Konawe dapat diketahui melalui hasil wawancara tokoh-tokoh adat dengan beberapa peneliti sejarah dan antropologi.

Pada tataran koherensi, proposisi bernilai benar bila proposisi itu mempunyai hubungan dengan ide-ide atau gagasan-gagasan dari proposisi terdahulu yang bernilai benar dalam suatu sistem pemikiran yang saling berhubungan secara logik-sistematik. Sebagai contoh jika kita ingin membuktikan bahwa runtuhnya Majapahit pada tahun 1478 atau 1400 Çaka dengan candra sangkala Sirna Ilang Kertaning Bumi. Maka, dalam pembuktian kebenaran itu kita tak dapat melihat langsung seperti para epistemologi realis tetapi harus melalui proposisi-proposisi terdahulu yang mewartakan tentang runtuhnya 
Majapahit. Proposisi itu dapat ditemukan dalam catatan sejarah atau catatan lain yang menguak kejadian itu. Dengan demikian, kebenaran pengetahuan itu dapat diuji melalui kejadian-kejadian sejarah atau data-data sejarah yang dapat dipertanggungjawabkan.

Kaitannya dengan SM, pembuktian kebenarannya dapat dilakukan melalui proposisi-proposisi terdahulu yang mewartakan kerajaan Konawe dan SM. Catatancatatan sejarah, khususnya laporan-laporan tertulis orang belanda dan orang Indonesia dapat dimanfaatkan untuk membuktikan kebenaran SM. Keberadaan Mokole Tebawo sebagai raja di Kerajaan Konawe abad ke XVII dapat diketahui melalui laporan Treffers, F. 1913. 'Drie verhalen afkomstig van de Tolaki', dalam Tijd., L.V. Vonk, J. 1928. Verstelg von Sangia Inato dochter von wasangguni \& Tawe Niroekoe. Kruijt A.C. 1922. 'Een en ander over de Tolaki van Mekongga', dalam Tijd., LXI. Kruijt, A.C dan J. Kruijt. 1921. 'Reise naar Kolaka' dalam TNAG, XXXVIII. Sarasin, P dan F. 1905. 'Reise von der Mingkoka-Bai nach Kendari, Sudost Celebes' dalam Reisen in Celebes, Wiesbaden. Tarimana, Abdurrauf, 1993. Kebudayaan Tolaki. Jakarta: Balai Pustaka. Tarimana, Abdurrauf, dkk. 1978. Dokumenta Historica DPRD TK I Sulawesi Tenggara. Kendari. Juga dapat memanfaatkan lontara'lontara' berbahasa bugis yang menyebutkan bahwa Mokele Tebawo merupakan saudara dari arumpone V Tenri Sukki Mappajunge (1510-1535). Dalam silsilah raja-raja Bone, Sangia Inato atau Mokole Tebawo diberi nama Tosangngeang dabali (dewa yang dibuatkan rumah).

SM merupakan hasil kesepakatan bersama antara raja/mokole dengan raja-raja bawahan di keempat SM. Pengujian kebenaran SM melalui perspektif ini akan mengungkapkan lebih jauh bahwa konsep SM sendiri bukanlah murni hasil pemikiran mokole sendiri. Hal ini dibuktikan bahwa selama pemerintahan Mokole Tebawo, raja-raja bawahan di keempat wilayah SM menyetujui konsep tersebut dan pengangkatan mereka sebagai raja-raja bawahan. Selain itu, keberadaan SM sendiri dalam konteks saat ini disepakati kebenarannya oleh beberapa tokoh adat, tokoh masyarakat, peneliti dan sejarawan lokal di Kabupaten Konawe. Meskipun demikian, penulis berpendapat bahwa diskusi atau pewacanaan tentang SM sebagai konsep politik di Kerajaan Konawe perlu terus dilakukan melalui pertemuan-pertemuan informal, dalam bentuk focus group discussion (FGD), yang melibatkan sejumlah tokoh yang kompeten dan otoritatif yang dapat memberi informasi valid tentang SM. Selama ini pertemuan-pertemuan yang melibatkan sejumlah tokoh dan intelektual yang kompeten dan otoritatif masih sebatas mendiskusikan adat tolaki secara umum. Lembaga Adat Tolaki (LAT) dalam sejumlah 
pertemuan formalnya masih sebatas mendiskusikan reaktualisasi adat Tolaki dalam semua segmen kehidupan di Konawe, Konawe Selatan, Konawe Utara dan Kota Kendari.

\section{KESIMPULAN}

Pada tataran epistemologi politik, penentuan wilayah di Kerajaan Konawe dilakukan dalam rangka memperkuat ketahanan politik dan ekonomi kerajaan Konawe. Secara politis, Mokole Tebawo mengangkat keturunannya dalam jabatan-jabatan strategis pada empat wilayah kerajaan yang disebut Siwole Mbatohu. Dengan cara ini, Mokole Tebawo ingin mengintegrasikan seluruh wilayah yang ada ke dalam kerajaan Konawe. Meski demikian, integrasi wilayah-wilayah ini tidak menafikan aspek otonomi pada masingmasing wilayah. Kerajaan-kerajaan penyangga diberi kewenangan penuh untuk memenuhi kebutuhan hidup masyarakatnya. Secara ekonomis, Siwole Mbatohu menempatkan keempat wilayah tersebut ke dalam posisi yang cukup strategis untuk pengembangan wilayah. Dengan dukungan sektor pertanian, maka keempat wilayah tersebut mampu mengelola sumber daya ekonominya.

Dalam konteks relasi kuasa-pengetahuan, konsep SM diproduksi dalam rangka memperkokoh relasi-relasi kekuasaan dengan raja-raja bawahan di kerajaan Konawe. Karena itu, pengetahuan selalui memiliki hubungan dengan kekuasaan. Terkait dengan teori kebenaran, pengujian validitas kebenaran pengetahuan SM dilakukan dengan memanfaatkan beberapa teori kebenaran, antara lain, Teori Korespondensi, koherensi, konsensus dan otoritarian. Melalui pemanfaatan bukti-bukti arkeologis, sumber-sumber sejarah tertulis, utamanya laporan tertulis orang-orang belanda dan sejarawan lokal dapat dilihat dan diketahui ekistensi kerajaan Konawe, mokole Tebawo dan Siwole Mbatohu. Selain itu, pada tataran konsensus, terdapat kesepakatan dari sejumlah tokoh adat dan intelektual yang meneguhkan kebenaran SM sebagai konsep falsafah politik yang pernah dijalankan oleh Mokole Tebawo atau Sangia Inato di kerajaan Konawe abad ke XVII. Sementara pada tataran otoritarian, pengujian kebenaran konsep falsafah politik SM dapat dilakukan melalui wawancara dengan sejumlah tokoh yang sangat otoritatif dan paling mengetahui konsep SM.

\section{Daftar Pustaka}

Abidin, Andi Zainal, Kapita Selecta Sejarah dan Kebudayaan Sulawesi Selatan. Ujungpandang: Hasanuddin University Press, 1999. 
. "Notes on the Lontara' as Historical Sources". Indonesia, No. 12 (Oktober) 1971. Ithaca, New York: Cornell Modern Indonesia Project, 1971.

Absori, Kelik Wardiono dan Saepul Rochman. Hukum Profetik: Kritik Terhadap Paradigma Hukum Non-Sistematik. Yogyakarta: Genta Publishing, 2015.

Ahimsa Putra, Heddy Shri. Minawang: Hubungan Patron Klien di Sulawesi Selatan. Yogyakarta: Gadjah Mada University Press, 1988.

Andrews, William G. Constitutions and Constitutionalism 3rd edition. New Jersey: Van Nostrand Company, 1968.

Asshiddiqie, Jimly Konstitusi dan Hukum Tata Negara Adat. Disampaikan sebagai bahan Keynote Speech pada Seminar Nasional tentang Konstitusi KesultananKesultanan Islam di Jawa Barat dan Banten. UIN Gunung Djati, Bandung, 5 April 2008.

Bhurhanuddin, B. dkk. Sejarah kebangkitan Nasional Daerah Sulawesi Tenggara. Jakarta:

Departemen Pendidikan dan Kebudayaan Pusat Penelitian Sejarh dan Budaya Proyek Penelitian dan pencatatan Kebudayaan Daerah, 1978/1979.

Dilthey, William. Dilthey: Selected writings, diedit oleh H.P Rickman, Cambridge: Cambridge University Press, 1976

Fadli, Moh. dkk, Pembentukan Peraturan Desa Partisipatif (Head To A Good Village Governance), UB Press, Malang, 2011.

Foucault, Michael. Discipline and Punish. Middlesex: Penguin Books, 1985.

. Histoire de la sexualité I. La volonté du savoir, Paris: Gallimard, 1976.

. Power/Knowledge (Selected Interviews and Other Writings 1972-1977). Sussex:

The Harvester Press, 1980.

. Surveiller et punir. Naissance de la prison, Paris: Gallimard, 1975.

Freeman, M.D.A. Lloyd's Introduction to Juricprudence, Seventh Edition, London: Sweet \& Maxweel Ltd., 2001.

Giddens, Anthony. Sociology. UK: Polity Press, 1997.

Habermas, Jurgen, The Theory of Communicative Action, volume 2, System and Lifeworld: A

Critique of Functionalist Reason. Boston, MA: Beacon Press, 1987.

Hardiman, Fransisco Budi, Kritik Ideologi: Pertautan Pengetahuan dan Kepentingan, Yogyakarta: Penerbit Kanisius, 1990.

. Demokrasi Deliberatif: Menimbang 'Negara Hukum' dan 'Ruang Publik' dalam

Teori Diskursus Jurgen Habermas, Yogyakarta: Penerbit Kanisius, 2009. 
Haryatmoko. "Kekuasaan-Pengetahuan Sebagai Rezim Wacana Sejarah Seksualitas:

Sejarah Pewacanaan Seks \& Kekuasaan Menurut Foucault" Makalah Seri Kuliah Umum Juni 2010, Makalah Disampaikan dalam Seri Kuliah Umum "Tentang Seksualitas" di Komunitas Salihara, Sabtu 12 Juni 2010.

Hoernie, R.F.A., Studies in Philosophy, London: George Allen \& Unwin Ltd., 1952

Hospers,J., An Introduction to Philosophical Analysis, Englewood Cliffs: Prentice-Hall, 1967. Ismi, Hayatul, "Pengakuan dan Perlindungan Hukum Hak Masyarakat Adat atas Tanah Ulayat dalam Upaya Pembaharuan Hukum Nasional", Jurnal Ilmu Hukum, Vol. 2, 2 Februari 2012.

James H. Morrison. "Perspektif Global Sejarah Lisan di Asia tenggara” dalam P. Lim Pui Huen et. Al (ed.), Sejarah Lisan di Asia Tenggara: Teori dan Metode. Jakarta: LP3ES, 2000.

Kruijt A.C. 'Een en ander over de Tolaki van Mekongga', dalam Tijd., LXI., 1922.

Kruijt, A.C dan J. Kruijt. 'Reise naar Kolaka' dalam TNAG, XXXVIII, 1921.

Mattulada, H.A. Latoa, Suatu Lukisan Analitis terhadap Antropologi Politik orang Bugis. Disertasi UI Jakarta, 1975.

Merquior, José-Guilherme, Foucault ou le nihilisme de la chaire, Paris: PUF, 1985.

Michele, Doherty. Jurisprudence: The Philosophy of Law, 2nd ed., London: Old Bailey Press, 2001.

Mintaredja, Abbas Hamami. Kebenaran; Suatu problema filsafat pengetahuan. Bahan kuliah. Yogyakarta: Fakultas Filsafat UGM, 2009.

Noorduyn, J. "Origins of South Celebes Historical Writing" dalam Soedjatmoko et al.,(ed.), An Introduction to Indonesian Historiography. $3^{\text {th }}$ edition. Ithaca and London: Cornell University Press, 1975.

Reimann, Mathias. The Historical School Against Codification: Savigny, Carter, and the Defeat of the New York Civil Code, 37 AM. J. COMP. L. 95, 97-98. 1989.

Santasombat, Yos. "Sejarah Lisan dan Potret Diri" dalam P. Lim Pui Huen et. Al (ed.), Sejarah Lisan di Asia Tenggara: Teori dan Metode. Jakarta: LP3ES, 1989

Sarasin, P dan F. 'Reise von der Mingkoka-Bai nach Kendari, Sudost Celebes' dalam Reisen in Celebes, Wiesbaden, 1905.

Su'ud, Muslimin. Peranan Kepemimpinan Kelembagaan Adat Kalosara dalam Pembinaan Tertib Sosial dan Tertib Hukum untuk Meningkatkan Partisipasi Masyarakat 
terhadap Pembangunan Masyarakat Pedesaan di Kabupaten Daerah Tingkat II Kendari. Laporan Penelitian. Kendari: Balai Penelitian Universitas Haluoleo, 1992.

Tafsir, Ahmad, Filsafat Umum: Akal dan Hati Sejak Thales sampai James. Bandung: PT. Remaja Rosdakarya, 1994.

Tarimana, Abdurrauf, dkk. Dokumenta Historica DPRD TK I Sulawesi Tenggara. Kendari, 1978.

Tarimana, Abdurrauf, Kebudayaan Tolaki. Jakarta: Balai Pustaka, 1993.

Tawulo, Asrul, dkk. Pranata Kepemimpinan Tusa wuta dalam Sistem Pertanian Masyarakat Tolaki di Kabupaten Kendari. Laporan Penelitian. Kendari: Balai Penelitian Universitas Haluoleo, 1991.

Treffers, F. 'Drie verhalen afkomstig van de Tolaki', dalam Tijd., L.V., 1913.

Vonk, J. Verstelg von Sangia Inato dochter von wasangguni \& Tawe Niroekoe, 1928.

White, A.R. Truth; Problem in Philosophy, New York: Doubleday\&Co, 1970.

Yamin, Muhammad. Naskah Persiapan Undang-Undang Dasar 1945, Djilid Pertama, Jakarta: Siguntang, 1959. 